\title{
Centennial black carbon turnover observed in a Russian steppe soil
}

\author{
K. Hammes ${ }^{1}$, M. S. Torn ${ }^{2}$, A. G. Lapenas ${ }^{3}$, and M. W. I. Schmidt ${ }^{1}$ \\ ${ }^{1}$ University of Zurich, Department of Geography, Physical Geography, Soil Biogeochemistry Group, Winterthurerstrasse 190, \\ 8057 Zurich, Switzerland \\ ${ }^{2}$ Lawrence Berkeley National Laboratory, Berkeley, CA 94720, USA \\ ${ }^{3}$ Department of Geography and Planning, University at Albany, NY 12222, USA
}

Received: 14 December 2007 - Published in Biogeosciences Discuss.: 13 February 2008

Revised: 2 July 2008 - Accepted: 18 August 2008 - Published: 18 September 2008

\begin{abstract}
Black carbon (BC), from incomplete combustion of fuels and biomass, has been considered highly recalcitrant and a substantial sink for carbon dioxide. Recent studies have shown that $\mathrm{BC}$ can be degraded in soils. We use two soils with very low spatial variability sampled 100 years apart in a Russian steppe preserve to generate the first wholeprofile estimate of BC stocks and turnover in the field. Quantities of fire residues in soil changed significantly over a century. Black carbon stock was $2.5 \mathrm{~kg} \mathrm{~m}^{-2}$, or about $7-10 \%$ of total organic $\mathrm{C}$ in 1900 . With cessation of biomass burning, BC stocks decreased $25 \%$ over a century, which translates into a centennial soil BC turnover (293 years best estimate; range 182-541 years), much faster than so-called inert or passive carbon in ecosystem models. The turnover time presented here is for loss by all processes, namely decomposition, leaching, and erosion, although the latter two were probably insignificant in this case. Notably, at both time points, the peak BC stock was below $30 \mathrm{~cm}$, a depth interval, which is not typically accounted for. Also, the quality of the fire residues changed with time, as indicated by the use benzene polycarboxylic acids (BPCA) as molecular markers. The proportions of less-condensed (and thus more easily degradable) BC structures decreased, whereas the highly condensed (and more recalcitrant) BC structures survived unchanged over the 100-year period. Our results show that BC cannot be assumed chemically recalcitrant in all soils, and other explanations for very old soil carbon are needed.
\end{abstract}

\section{Introduction}

Black carbon (BC) is a product of incomplete combustion of fossil fuels and biomass burning (Goldberg, 1985) and

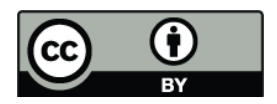

Correspondence to: M. W. I. Schmidt (michael.schmidt@geo.uzh.ch) is found in almost every environment, either formed in situ or transported through various means, including aeolian and riverine transport (Kuhlbusch, 1998). BC deposited in soil constitutes a significant, yet relatively poorly understood component of soil organic carbon (Schmidt, 2004). Until recently, $\mathrm{BC}$ was thought to be generally recalcitrant, with an average turnover rate in soil of thousands of years. This assumption was based on charcoal findings in soil that were radiocarbon dated to be thousands of years old (Skjemstad et al., 1996; Forbes et al., 2006), as well as evidence of millennial turnover of $\mathrm{BC}$ in marine sediments (Masiello and Druffel, 1998). This inert character has made BC an ideal candidate for an atmospheric carbon sink (Kuhlbusch, 1998). However, significant BC degradation has been observed in Atlantic marine sediments, where a relict turbidite lost around 64\% BC over 10-20 thousand years (Middelburg et al., 1999). Additionally, recent short-term laboratory and field studies have shown evidence for degradation of $\mathrm{BC}$ in soil (Bird et al., 1999; Hamer et al., 2004; Brodowski, 2005; Hockaday et al., 2006). Incubation studies, conducted for two months to two years, show BC turnover times of decades (Hamer et al., 2004; Brodowski et al., 2005). However, these incubation studies have limitations that make extrapolation of data difficult: (i) only topsoil was incubated (to $20 \mathrm{~cm}$ ) and the studies were (ii) short-term, (iii) represented laboratory conditions, and (iv) used char produced artificially and at low temperature. Direct field measurements and long-term, in situ confirmation of how stable this material is, i.e. what $\mathrm{BC}$ turnover times are in the environment, are still lacking. We took advantage of a 100 -year interval soil sampling of a Russian Chernozem to study long-term change of $\mathrm{BC}$ in the field.

Chernozems are the 8th most common soil order, covering approximately $7 \%$ of earth's ice-free land area (Bell and McDaniel, 2000). Nearly all of the 117 million ha of Chernozems in the Russian steppe and 12 million ha of Chernozems in the Ukrainian steppe are used for agriculture

Published by Copernicus Publications on behalf of the European Geosciences Union. 
(Stolbovoi and McCallum, 2002). Russian Chernozems have substantial organic carbon stocks of $28-34 \mathrm{~kg} \mathrm{~m}^{-2}$ for the top $1 \mathrm{~m}$ under native (undisturbed) grassland (Torn et al., 2002; Mikhailova, 2006). Native Chernozem grasslands can be found only in a few preserves, including the Kamennaya Steppe Preserve created between 1882 and $1885\left(51^{\circ} 0^{\prime} \mathrm{N}\right.$, $40^{\circ} 7^{\prime} \mathrm{E}$, Lapenis et al., 2000).

At about the same time as the Kamennaya Steppe preserve establishment, almost all of the region's steppe was converted to agriculture and, most importantly for our study, fires which were frequent on the steppe, were suppressed by human activity, resulting in almost total cessation of once frequent biomass burning inputs of $\mathrm{BC}$ to soil. These circumstances gave us the unique opportunity to document the change in $\mathrm{BC}$ stocks over time, and to estimate a turnover time of BC in soil, in study with the following advantages: (i) a long time period (ca. 100 years), (ii) an in situ field site, (iii) natural char produced in situ, (iv) a deep soil profile ( $>1 \mathrm{~m}$ ) and (v) no known land use change or disturbance. Currently, estimates of black carbon stocks and turnover in soil are major gap in understanding of the global carbon cycle (Schmidt 2004).

\section{Materials and methods}

\subsection{Field site and climate}

Soils were collected in the land holdings of the Dokuchaev Institute, in the $\sim 5000$-ha Kamennaya Steppe Preserve $\left(51^{\circ} 01^{\prime} \mathrm{N}\right.$ and $\left.40^{\circ} 43^{\prime} \mathrm{E}\right)$. The soils were developed on loess and clay deposited around 4500-6000 years ago during the mid-Holocene (Ivanov 1991) and categorized as Chernozems.

The mean annual temperature from $1989-1998$ was $6.6^{\circ} \mathrm{C}$ and from $1893-1950$ was $5.3^{\circ} \mathrm{C}$. Mean annual rainfall from 1989-1998 was $507.7 \mathrm{~mm}$, an increase of $70 \mathrm{~mm}$ (mostly winter precipitation) over the 1893-1950 average $(438.5 \mathrm{~mm})$ (Sentsova, 2002). Additional information on the climate conditions in the area can be found at: http: //data.giss.nasa.gov/gistemp/station_data/ using the stations Kamennaja Ste $\left(51^{\circ} 0^{\prime} \mathrm{N}, 40^{\circ} 7^{\prime} \mathrm{E}\right)$ and Voronez $\left(51^{\circ} 7^{\prime} \mathrm{N}\right.$, $\left.39^{\circ} 2^{\prime} \mathrm{E}\right)$.

\subsection{Soil sampling}

The 100-year old soil monolith was collected between 1895 and 1903 (called 1900 soil from here on) and is almost $140 \mathrm{~cm}$ deep. According to the original sampling notes and current observations, the monolith was sampled without disturbing the horizon structure, and kept horizontal without any resin treatment in a wood box to keep it dust-free. The location of the sampled site and the collection procedures were detailed previously (Lapenis et al., 2000; Torn et al., 2002). In August 1997, one soil profile was sampled from almost exactly the same location (within meters) under the same land use and a second profile (1997-2) was collected under the same preserved land cover approximately $1 \mathrm{~km}$ away within the reserve (Torn et al., 2002). Samples were collected from the wall of a pit dug for this purpose, starting from the bottom and sampling in a channel over the whole of each horizon or depth increment. Soil organic carbon and carbon isotopes $\left({ }^{13} \mathrm{C}\right.$ and $\left.{ }^{14} \mathrm{C}\right)$ in archived and both 1997 profiles were measured by Torn et al. (2002). For this study, BC was measured in the archived and main (co-located) 1997 profile, as well as in soils collected in 2004.

In addition to the 1900 and 1997 samplings, an additional Chernozem soil profile was sampled in August 2004 under the same steppe land cover roughly $1 \mathrm{~km}$ from the main 1900 and 1997 pits and near the 1997-2 profile (Table 1). This soil was sampled to a depth of $100 \mathrm{~cm}$ after scraping away the open wall of an existing soil pit. Samples were collected from the wall of the pit, starting from the bottom and sampling in a channel over the whole of each horizon. A plowed soil profile was also sampled next to the pristine steppe profile, in $10 \mathrm{~cm}$ depth increments, to $70 \mathrm{~cm}$ deep.

In calculating BC stock, we used bulk densities measured by Torn et al. (2002) in the two 1997 soil profiles (Table 1; averaged for each depth increment), and assumed bulk density to be the same in 1900 . There was a good correlation between the 1900 profile and the two 1997 soils for both $\mathrm{C}$ content and thickness of all horizons, supporting the assumption that the soil bulk density was similar (Torn et al., 2002). The measured bulk density values were interpolated and applied to the soil sampled in 2004 according to the sampling depth increments. Because sampling depth increments in 2004 were not the same as those in 1900 and 1997 soils, it was possible to compare $2004 \mathrm{BC}$ stock for the whole profile but not horizon by horizon.

\subsection{Representativeness of the soil monoliths}

The watershed of the Kamennaya Steppe Preserve sits on aeolian deposits (yellow carbonate loess). Therefore, there is little spatial variation in the soil parent material, and the topography is very flat. The typical variation in height is on order of $5 \mathrm{~m}$ per km (except a few gullies). Replicate soil profiles sampled $1 \mathrm{~km}$ apart in 1997 had similar carbon content and horizon characteristics with depth (Table 1). We believe that the soil profiles sampled in 1900, 1997 and 2004, and analyzed here, are fairly representative of soil conditions under pristine steppe at the time of sampling, since the landscape is homogenous and there was little variation among replicate soil pits sampled in 1997.

\subsection{Black carbon analysis}

We analyzed BC in each soil sample using benzene polycarboxylic acids (BPCAs) as markers for the presence of firederived organic matter (Brodowski et al., 2005). Briefly, triplicate samples were digested with $\mathrm{HNO}_{3}$ at $170^{\circ} \mathrm{C}$ for eight 
Table 1. Selected characteristics of soil profiles. The site sampled in 1900 and 1997 is compared to three other soil profiles about $1 \mathrm{~km}$ away sampled in 1997 (1997-2) and 2004. All of the soils were developed on the same loess parent material.

\begin{tabular}{|c|c|c|c|c|c|}
\hline $\begin{array}{l}\text { Sampling year } \\
\text { (description) }\end{array}$ & $\begin{array}{l}\text { Depth } \\
\mathrm{cm}\end{array}$ & $\begin{array}{c}\text { Bulk density } \\
\mathrm{g} \mathrm{cm}^{-3}\end{array}$ & $\begin{array}{l}\text { Organic carbon } \\
\mathrm{g} \mathrm{kg}^{-1} \text { dry weight }\end{array}$ & $\begin{array}{c}\delta^{13} \mathrm{C} \text { of } \mathrm{OC} \\
\% \circ\end{array}$ & $\begin{array}{c}\text { Black carbon } \\
\mathrm{g} \mathrm{kg}^{-1} \text { dry } \\
\text { weight } \\
\text { (standard } \\
\text { deviation) }\end{array}$ \\
\hline $\begin{array}{l}1900^{\mathrm{a}} \\
\text { (archive steppe soil) }\end{array}$ & $\begin{array}{c}0-5 \\
5-12 \\
12-20 \\
20-36 \\
36-50 \\
50-65 \\
65-78 \\
78-100 \\
100-120 \\
120-134\end{array}$ & $\begin{array}{l}0.52 \\
0.68 \\
0.73 \\
0.86 \\
0.85 \\
1.12 \\
1.17 \\
1.23 \\
1.24 \\
1.32\end{array}$ & $\begin{array}{l}105.3 \\
81.5 \\
59.7 \\
45.9 \\
38.2 \\
31.7 \\
17.2 \\
7.7 \\
4.7 \\
5.1\end{array}$ & $\begin{array}{l}-25.8 \\
-25.9 \\
-25.4 \\
-25.3 \\
-25.4 \\
-25.4 \\
-24.8 \\
-24.2 \\
-23.6 \\
-23.8\end{array}$ & $\begin{array}{l}7.62 \pm 1.0 \\
6.32 \pm 0.8 \\
5.78 \pm 0.2 \\
4.91 \pm 1.1 \\
4.17 \pm 0.8 \\
2.11 \pm 0.1 \\
1.15 \pm 0.3 \\
0.01 \pm 0.0 \\
0.03 \pm 0.0 \\
0.01 \pm 0.0\end{array}$ \\
\hline $\begin{array}{l}1997^{\text {a }} \\
\text { (sampled at site of } \\
\text { archive steppe soil) }\end{array}$ & $\begin{array}{c}0-5 \\
5-13 \\
13-21 \\
21-37 \\
37-45 \\
45-53 \\
53-68 \\
68-90 \\
90-107 \\
107-130\end{array}$ & $\begin{array}{l}0.52 \\
0.82 \\
0.84 \\
0.86 \\
0.99 \\
1.12 \\
1.32 \\
1.32 \\
1.32 \\
1.32\end{array}$ & $\begin{array}{c}100.3 \\
61.0 \\
55.3 \\
46.6 \\
36.7 \\
25.9 \\
13.4 \\
8.7 \\
4.0 \\
7.4\end{array}$ & $\begin{array}{l}-28.0 \\
-26.2 \\
-26.0 \\
-25.8 \\
-25.6 \\
-25.6 \\
-25.0 \\
-24.9 \\
-24.7 \\
-24.0\end{array}$ & $\begin{array}{l}5.10 \pm 0.5 \\
4.99 \pm 1.0 \\
5.17 \pm 0.3 \\
4.38 \pm 0.7 \\
3.26 \pm 0.8 \\
2.30 \pm 0.0 \\
0.18 \pm 0.1 \\
0.02 \pm 0.0 \\
0.01 \pm 0.0 \\
0.01 \pm 0.0\end{array}$ \\
\hline $\begin{array}{l}1997-2^{\mathrm{a}} \\
\text { (sampled ca. } 1 \mathrm{~km} \\
\text { from archive steppe } \\
\text { soil) }\end{array}$ & $\begin{array}{c}0-5 \\
5-12 \\
12-20 \\
20-36 \\
36-50 \\
50-58 \\
58-75 \\
75-82 \\
82-102 \\
102-122 \\
122-142\end{array}$ & $\begin{array}{l}0.61 \\
0.68 \\
0.73 \\
0.72 \\
0.85 \\
1.01 \\
1.17 \\
1.20 \\
1.23 \\
1.24 \\
1.24\end{array}$ & $\begin{array}{l}78.0 \\
68.0 \\
66.2 \\
49.6 \\
34.9 \\
28.6 \\
21.6 \\
17.3 \\
6.5 \\
4.8 \\
4.5\end{array}$ & $\begin{array}{l}-27.7 \\
-25.8 \\
-25.6 \\
-25.4 \\
-25.2 \\
-24.5 \\
-25.0 \\
-25.0 \\
-24.8 \\
-24.0 \\
-23.3\end{array}$ & $\begin{array}{l}- \\
- \\
- \\
- \\
- \\
- \\
- \\
- \\
- \\
- \\
-\end{array}$ \\
\hline $\begin{array}{l}2004 \\
\text { (sampled ca. } 1 \mathrm{~km} \\
\text { from archive steppe } \\
\text { soil) }\end{array}$ & $\begin{array}{c}0-5 \\
5-20 \\
20-50 \\
50-80 \\
80-100\end{array}$ & $\begin{array}{l}0.52 \\
0.83 \\
0.99 \\
1.25 \\
1.25\end{array}$ & $\begin{array}{l}74.2 \\
55.7 \\
28.8 \\
26.0 \\
27.5\end{array}$ & $\begin{array}{l}-25.9 \\
-25.4 \\
-25.0 \\
-24.9 \\
-21.4\end{array}$ & $\begin{array}{l}6.11 \pm 0.6 \\
7.48 \pm 1.8 \\
2.35 \pm 0.8 \\
0.78 \pm 0.3 \\
0.01 \pm 0.0\end{array}$ \\
\hline $\begin{array}{l}\text { 2004-plowed } \\
\text { (sampled ca. } 1 \mathrm{~km} \\
\text { from archive steppe } \\
\text { soil) }\end{array}$ & $\begin{array}{c}0-10 \\
10-20 \\
20-30 \\
30-40 \\
40-50 \\
50-60 \\
60-70\end{array}$ & $\begin{array}{l}0.77 \\
0.93 \\
0.93 \\
0.91 \\
0.94 \\
0.97 \\
0.95\end{array}$ & $\begin{array}{l}47.3 \\
45.5 \\
44.0 \\
41.4 \\
33.4 \\
30.8 \\
33.0\end{array}$ & $\begin{array}{l}-25.0 \\
-25.0 \\
-24.9 \\
-24.8 \\
-24.9 \\
-25.3 \\
-25.2\end{array}$ & $\begin{array}{l}4.41 \pm 0.4 \\
4.05 \pm 0.9 \\
3.88 \pm 0.6 \\
5.49 \pm 0.0 \\
2.88 \pm 0.8 \\
1.34 \pm 0.2 \\
0.24 \pm 0.1\end{array}$ \\
\hline
\end{tabular}

${ }^{a}$ Data based on Torn et al. (2002). 
hours, purified, and the sum of BPCAs in each sample analyzed after derivatization on a gas chromatograph equipped with a flame ionization detector. The error bars for each point on the graphs are the standard errors of two to three single analyses of dry weight soil. In published literature, BPCA data has sometimes been multiplied with a conversion factor of 2.27 to compensate for incomplete $\mathrm{BC}$ recovery (Brodowksi et al., 2005). However, this factor is currently disputed and we did not use it for our results. Furthermore, the BPCA method was recently evaluated in a comparison of different BC methods used for soils and sediments (Hammes et al., 2007). This study concluded that different methods measure different parts of the $\mathrm{BC}$ continuum, with varying biases due to non-BC being measured as $\mathrm{BC}$. Some of the most important results of that comparison for the present study were that the BPCA method (i) can be used for a conservative quantification of $\mathrm{BC}$ in a soil matrix, (ii) yields information on $\mathrm{BC}$ quality (reflected by its molecular marker pattern), and (iii) can be reproduced with a standard error $(<10 \%)$ typical for many measurements in environmental matrices, including soil.

\subsection{Statistics}

A one-tailed t-test with matched pairs was done to test the hypothesis that the 1997-soil does not have less BC than the archive soil (JMP 5.1.2, SAS). The statistical test was done on pair-wise (comparable-depths) horizon samples, 10 horizons for each profile.

\subsection{Estimating turnover time}

We estimated $\mathrm{BC}$ turnover time with the approach used to estimate SOC turnover time in many ${ }^{13} \mathrm{C}$ and ${ }^{14} \mathrm{C}$ isotopic studies (e.g., Balesdent et al. 1988; Trumbore, 1993; Veldkamp, 1994) and most ecosystem models, including Century, CASA, IBIS-2, and Rothamsted (Randerson et al., 1996; Kucharik et al., 2001; Parton et al., 1994; Jenkinson, 1990). Specifically, we model outflow of BC from soil as a linear, donor-controlled (i.e., first-order decay) process in which loss is linearly proportional to stock, and assume that the $\mathrm{C}$ pool is well mixed such that all $\mathrm{C}$ in the pool has an equal probability of loss at any time. Thus: outflow $\left(\mathrm{kg} \mathrm{m}^{-2} \mathrm{y}^{-1}\right)=\mathrm{k} S=\mathrm{S} / \tau$, where $\mathrm{S}=$ black carbon stock $\left(\mathrm{kg} \mathrm{m}^{-2}\right), \mathrm{k}=$ decay constant $\left(\mathrm{y}^{-1}\right)$ and $\tau=$ turnover time $(\mathrm{y})=1 / \mathrm{k}$. BC inputs $\left(I, \mathrm{~kg} \mathrm{~m}^{-2} \mathrm{y}^{-1}\right)$ are largely a function of plant biomass and combustion, and thus are largely independent of BC stock in soil. Therefore, the change in BC stock with time, inputs minus outputs, can be expressed as:

$$
\frac{d S}{d t}=I-\frac{S}{\tau}
$$

Integrated to obtain an expression for BC stocks with time, the equation above yields:

$$
S(t)=I-\left(I-S_{0}\right) e^{-t_{/ t}}
$$

To use this equation to solve for turnover time, we assume that before 1900, BC stock was in equilibrium with historic $\mathrm{BC}$ inputs, so $\mathrm{S}_{0}=\mathrm{I}_{0} \tau$. This is parallel to the common assumption in SOC modeling that SOC stock is in equilibrium with NPP and at steady state. To assist in removing redundant terms, we define two dimensionless variables: First, around 1900 black carbon inputs fell to a fraction, $f$, of their former input level, so $\mathrm{I}=f \mathrm{I}_{0}$. Second, we define $b$, the fraction of original $\mathrm{BC}$ remaining $\left(b=\mathrm{S} / \mathrm{S}_{0}\right)$.

With those substitutions, Eq. 2 was rearranged to solve for $\tau$ :

$\tau=\frac{-t}{\left(\ln \frac{f-b}{f-1}\right)}$

The final consideration for soil $\mathrm{C}$ models is the number of pools to model. SOC is modeled with varied levels of complexity, with some models having multiple $\mathrm{C}$ pools, such as active, slow, and passive, and others having only one. One approach to separating SOC into pools of different turnover time is to physically isolate fractions of different density, size, position relative to aggregates, or chemical composition, and then treat each fraction as a homogeneous pool. Following this approach, we assumed that BC is homogeneous with respect to turnover; in other words, all $\mathrm{BC}$ has the same turnover time and same probability of being lost, regardless of depth in soil or original source. This simplification has also been used in some ${ }^{13} \mathrm{C}$-based modeling using a shift between $\mathrm{C}_{3}$ and $\mathrm{C}_{4}$ vegetation, in some ${ }^{14} \mathrm{C}$ turnover studies, and by others. In reality, SOC, and thus presumably $\mathrm{BC}$ as well, comprises a wide range of chemical forms and is found in small and large particles, occluded in aggregates, and associated with minerals, that lead to different turnover times. Given sufficient data, it would be possible to model each fraction as two or more pools. We adopt a one-pool approach because we do not have enough data to constrain a multi-pool model. Nevertheless, studies using fractions to enable modeling SOC as multiple pools represent an improvement over modeling all SOC as one pool. To summarize, for this model we made four assumptions: (1) loss of $\mathrm{BC}$ from the soil is a first order decay process; (2) BC is homogenous with respect to turnover, (3) the BC stock in 1900 was in equilibrium with BC inputs; and (4) after the 1900 sampling, BC inputs decreased in accord with the decrease in regional fire frequency. The turnover time presented here is for loss by all processes, including decomposition, leaching, and erosion. Based on the mathematical model, the rate of loss with respect to decomposition alone is slower than whatever value is obtained for loss with respect to all processes combined.

Variables Legend:

$S=$ stock of black carbon, $\mathrm{kg} \mathrm{m}^{-2}, S_{0}=$ archive stock of BC

$b=0.75=S / S_{0}$

$t=$ time, y since original sampling.

$\tau=$ turnover time $(\mathrm{y})=1 / \mathrm{k}$, where $\mathrm{k}=$ decay constant 


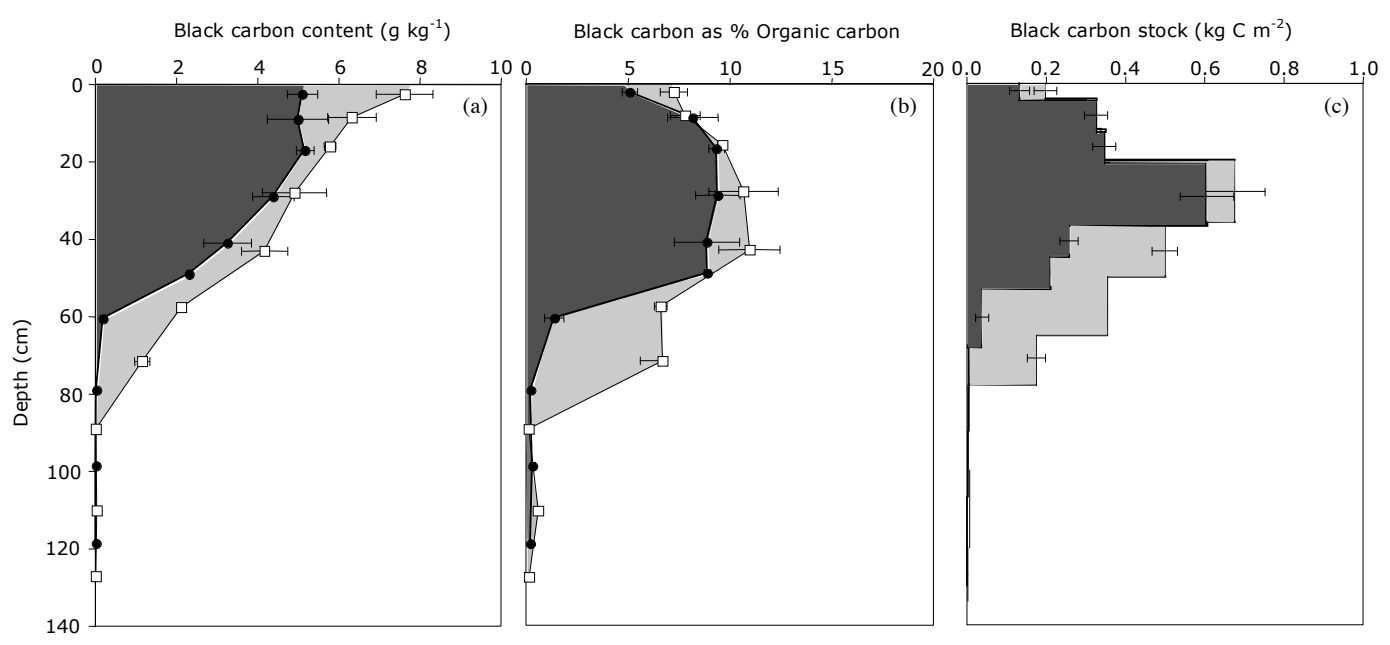

Fig. 1. (a) Black carbon concentrations ( $\mathrm{g} \mathrm{kg}^{-1}$ dry weight soil) of the 1900 soil (thin black line, open squares) and 1997 soil (thick black line, filled circles). The data are without the 2.27 correction factor often used with the BPCA method to compensate for the fact that not all BC is converted to BPCA (Brodowski et al., 2005). Error bars show the standard deviation of replicate laboratory analyses $(n=2-3$ per soil sample). (b) Black carbon as proportion of organic carbon for the 1900 and 1997 soils. (c) Black carbon stock of the 1900 and 1997 soils.

$\mathrm{I}=\mathrm{BC}$ input flux to soil, $\mathrm{kg} \mathrm{m}^{-2} \mathrm{y}^{-1}$

$\mathrm{I}_{0}=$ historic BC input, $\mathrm{kg} \mathrm{m}^{-2} \mathrm{y}^{-1}$.

$f=$ ratio of modern input flux to historic input flux. (fI $\mathrm{I}_{0}=$ inputs after $1900, \mathrm{~kg} \mathrm{~m}^{-2} \mathrm{y}^{-1}$ )

2.7 Sensitivity analysis for model estimates of turnover time

Using Eq. 3, we estimated $\tau$ for a range of plausible values of $t, b$, and $f$ to take into account our uncertainty in the original sampling date, the bulk density of $\sim 1900$ soils, and the reduction in BC inputs post 1900, respectively. The scenarios used to explore the effect of parameter uncertainty on our estimated turnover times are described here and summarized in Table 2. The archive soil was sampled somewhere between 1895 and 1903 , so we used a range of $t=94$ to 102 years to test model sensitivity to the time interval between sampling. We cannot rule out the possibility that bulk density changed over the 100 year period, although this change is likely to be small because carbon density and horizon thickness were not different between the 1900 and 1997 sampling (bulk density was only measured in 1997). We varied the bulk density used in calculating the 1900 stock by $\pm 10 \%$, which resulted in a range for the BC stock in 1900 of $2.3-2.8 \mathrm{~kg} \mathrm{~m}^{-2}$, and therefore different values of $b$. For example, if there was no change in bulk density between modern and 1900 samplings, then $b=1.92 \mathrm{~kg} \mathrm{C} \mathrm{m}^{-2} / 2.55 \mathrm{~kg} \mathrm{C} \mathrm{m}^{-2}=0.75$. Finally, the fire frequency in the region decreased after the Preserve was established, and thus so did $\mathrm{BC}$ input to the soil. We cannot quantify the precise reduction in $\mathrm{BC}$ input, but note that less than $5 \%$ of the Preserve has burned since its inception. We explored input levels from $f=0$ to 0.2 , meaning black $\mathrm{C}$ inputs after 1900 fell to $0 \%$ of historic black C inputs (i.e., no $\mathrm{BC}$ input for the past 100 years) to $20 \%$ of historic levels. If we assume long-range input of $\mathrm{BC}$ via aerial transport (Koch and Hansen, 2005) and accordingly increase the input fraction, this would result in faster turnover times for BC in this soil. For such input estimates, however, note that BC as defined for atmospheric measurements is not equal to $\mathrm{BC}$ as defined for soils and sediments (Andreae and Gelencsér, 2006; Hammes et al., 2007).

\section{Results and discussion}

\subsection{Black carbon concentrations}

Few other studies to date have quantified BC concentrations over the whole soil profile (see Kleber et al., 2003; Wang et al., 2005; Rodionov et al., 2006). Most BC concentration studies report only the topsoil values (to $30 \mathrm{~cm}$ depth). However, the observed maximum concentration of BC (Fig. 1a; reported as $\mathrm{gBC} \mathrm{kg}^{-1}$ soil dry weight, determined as total BPCA without correction factor throughout the paper) in our study was below the topsoil. BC made up a substantial $7 \%$ of $\mathrm{OC}$ in the whole profile in these soils, with a maximum contribution to OC of about $10 \%$ at $30-50 \mathrm{~cm}$ (Fig. 1b). The 2004 BC concentrations also decreased with depth, but this soil had its maximum concentration closer to the surface (5$20 \mathrm{~cm}$, data not shown). Studies limited to surface horizons miss the location of the most concentrated BC, and where BC contributes most to soil organic C. Analyzing BC with the same method, another study on Russian Chernozems further north (Kursk) also found the maximum BC concentration between 30 and $50 \mathrm{~cm}\left(49-75 \mathrm{~g} \mathrm{BC} \mathrm{kg}^{-1} \mathrm{C}\right.$ with the correction factor, 22-33 $\mathrm{g} \mathrm{BC} \mathrm{kg}^{-1} \mathrm{C}$ without) (Rodionov et al., 2006). 
Table 2. Modeling parameters for the sensitivity analysis, depicting three scenarios of black carbon turnover time: best estimate, minimum and maximum (see text and Fig. 5 caption for details).

\begin{tabular}{llllll}
\hline Scenario & $t$ & $f$ & $S_{0}$ & $\begin{array}{l}b \\
S=1.92\end{array}$ & \\
& & & & & \\
\hline Best estimate & 94 & 0.1 & 2.55 & 0.75 & 292 \\
Min. (+10\% BD) & 94 & 0.2 & $2.55 \times 1.1$ & 0.684 & 182.0 \\
Max. (-10\% BD) & 102 & 0.0 & $2.55 \times 0.9$ & 0.837 & 541.2 \\
\hline
\end{tabular}

where

$t=$ time between samplings (years)

$f=$ ratio of modern BC input flux to historic input flux (0-10\% BC input)

$S_{0}=$ archive stock of black carbon $\left(\mathrm{kg} \mathrm{m}^{-2}\right)$

$S=$ stock of black carbon $\left(\mathrm{kg} \mathrm{m}^{-2}\right)$

$b=$ fraction of original BC stock remaining (dependent on change in bulk density)

$\tau=$ turnover time (years)

$\mathrm{BD}=$ bulk density

That study did not report BC stocks or bulk density, and almost no other studies have either, making it almost impossible to determine storage and $\mathrm{BC}$ turnover rates in other soils (Preston and Schmidt, 2006). Interestingly, the 1997 BC concentrations are significantly lower than the 1900 BC concentrations throughout the soil $(P=0.015)$, decreasing with depth to almost zero at around $120-130 \mathrm{~cm}$ (Fig. 1a).

\subsection{Black carbon stocks}

The profile-total black carbon stocks of the 1997 and 2004 soils are $25 \%$ lower than that of the 1900 soil $\left(1.9 \mathrm{~kg} \mathrm{C} \mathrm{m}^{-2}\right.$ and $2.0 \mathrm{~kg} \mathrm{C} \mathrm{m}^{-2}$ vs. $2.5 \mathrm{~kg} \mathrm{C} \mathrm{m}^{-2}$, respectively, Fig. 2). Our results suggest that $\mathrm{BC}$ was lost from the soil over 100 years. Other studies, summarized by Forbes et al. (2006), indirectly suggest substantial losses of BC in other soils in hundreds of years, also when inputs were reduced. While the BC stocks for the 1900 and 1997 soils are similar in the top $20 \mathrm{~cm}$, in the $40-80 \mathrm{~cm}$ region the 1997 soil has a consistently lower BC stock than the historic, 1900 soil (Fig. 1c and Fig. 2). Data on soil BC stocks worldwide are scarce (Preston and Schmidt, 2006) and no data were found on other Russian Chernozems. BC stock (using the same quantification method as in the present study) in a German Chernozem was lower than at our site, with $1.0 \mathrm{~kg} \mathrm{~m}^{-2}$ to $1 \mathrm{~m}$ depth, but as in our study they found larger BC stock in the subsoil than in the topsoil (Kleber et al., 2003). For comparison with our surface soil BC stocks (Fig. 1c), in the surface soil of a North American prairie, $\mathrm{BC}$ stocks were $0.1-1.5 \mathrm{~kg} \mathrm{~m}^{-2}$ for the top $10 \mathrm{~cm}$ (Glaser and Amelung, 2003). In a study using a different BC quantification method (UV oxidation), BC stocks were $0.3-$ $0.4 \mathrm{~kg} \mathrm{~m}^{-2}$ for the top $20 \mathrm{~cm}$ under mixed-grass savanna in

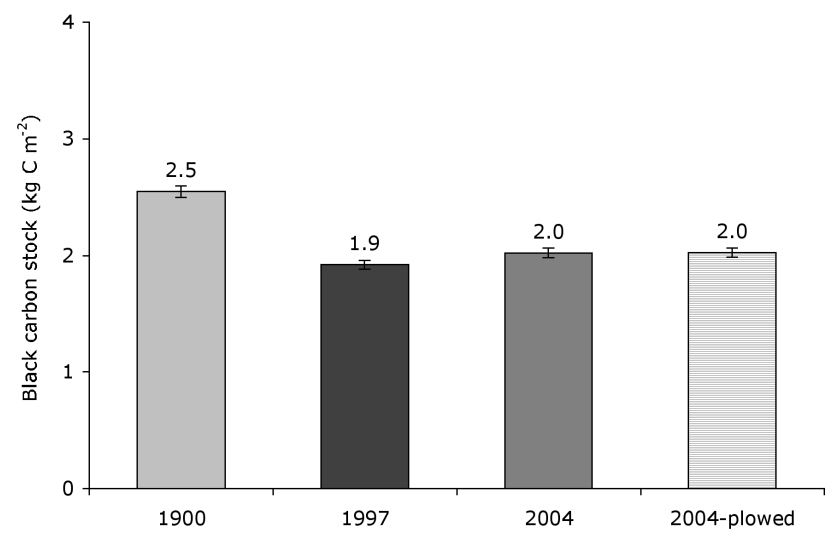

Fig. 2. Total profile BC stocks of steppe soil sampled in 1900, 1997 and 2004. Error bars show the standard deviation of replicate laboratory analyses ( $n=2-3$ per soil sample). The BC stock decreased $25 \%$ between 1900 and 1997 . The comparative 2004 soils are also about $25 \%$ lower.

Texas (Ansley et al., 2006). The stock in the top $5 \mathrm{~cm}$ of a savanna soil in Zimbabwe was $0.04 \mathrm{~kg} \mathrm{~m}^{-2}$ (using a dichromate oxidation method) (Bird et al., 1999). The fact that BC stocks are usually only determined for the top $10-20 \mathrm{~cm}$ means that most studies dramatically underestimate the black carbon (and carbon) stocks of deep, carbon-rich soils (Torn et al., 2002; Preston and Schmidt, 2006). The total carbon stocks, and sink or source potential, in these soils is much larger than that conveyed by only considering the topsoil.

\subsection{Quality of black carbon}

An advantage of the BPCA method above other BC quantification methods is that it can give an indication of the change in quality of BC in a soil. A change in black carbon structure during the course of degradation is mirrored by the BPCA pattern. The BPCA markers used in our quantification method were formed during the $\mathrm{HNO}_{3}$ oxidation of $\mathrm{BC}$. The maximum number of carboxylic groups reflects the number of formerly found quaternary $\mathrm{C}$ atoms (Brodowski, 2005). Thus, BC with a higher degree of condensation should result in higher proportions of the penta(B5CA) and hexacarboxylic (B6CA) benzoic acids relative to BPCAs with less quaternary $\mathrm{C}$ atoms (B3CA, B4CA) (Brodowski et al., 2005, 2007). In other words, if BPCA analysis yields larger proportions of B6CA, this indicates larger proportions of highly condensed BC (recalcitrant) structures compared to less condensed (and more degradable) BC particles. And indeed, Fig. 3 shows increasing proportions of B6CA released from highly condensed (recalcitrant) BC structures over the 100-year period. Also, the pattern of all BPCA (Fig. 4) shows one clear trend. The proportions of less-condensed (and thus more easily degradable) BC structures decreased, reflected by decreasing proportions of B3CA to B5CA, whereas the highly condensed (and more 
recalcitrant) $\mathrm{BC}$ structures survived, reflected by constant stocks of B6CA. Again, the B6CA can only be released from the highly condensed aromatic core (the backbone) of $\mathrm{BC}$, which obviously was more or less unchanged over the 100year period. A possible trend for the future could be that $\mathrm{BC}$ degradation will level off, once the less-condensed BC structures have been degraded and the highly condensed (and more recalcitrant) $\mathrm{BC}$ structures survive.

\subsection{Black carbon turnover time}

Having a difference in $\mathrm{BC}$ stock between two points in time, along with a known reduction in $\mathrm{BC}$ inputs, allowed us to estimate the turnover time of $\mathrm{BC}$ with a simple model. We estimated the maximum turnover time of $\mathrm{BC}$ in this soil to be 541 years, and the minimum to be 182 years, with the range due to uncertainty in sampling interval, fire cessation, and bulk density (Table 2, Fig. 5). The conservative, maximum turnover time of 541 years is calculated assuming post1900 inputs of BC were reduced completely, bulk density had increased by $10 \%$ over the 100 -year period, and the soil was sampled in the earliest year mentioned $(1895 ; t=102 \mathrm{y}$ from the time of 1997 re-sampling). Our best estimate, calculated with previously published values for sampling date (1903) and bulk density (no change from present), and the assumption of a $90 \%$ reduction in pre-1900 BC inputs from biomass burning, is $293 \mathrm{y}$. In the Zimbabwe study, which looked at soil BC stocks 50 years after burning had stopped, soil BC had a turnover time between 50 and 100 years, which is faster than ours, but it was estimated only for $0-5 \mathrm{~cm}$ and in a warm, tropical climate (Bird et al., 1999).

The estimated turnover times were reasonably robust despite uncertainty in some parameters. Figure 5 and Table 2 show the sensitivity of our estimated turnover times to uncertainty in: the time since sampling, reduction of BC inputs post 1900 , and bulk density of the 1900 soil which affects $b$. Each line shows $\tau$ for a different combination of $t$ and $f$ (i.e., for a given line, $t$ and $f$ are fixed while bulk density varies on the $\mathrm{x}$-axis). Lines $\mathrm{A}$ and $\mathrm{B}$ have combinations of $t$ and $f$ that produce the minimum and maximum possible $\tau$ within our estimated uncertainty ranges. The figure shows that our estimate of $\tau$ is most sensitive to uncertainty in bulk density of the 1900 soil, with an approximate two-fold increase in $\tau$ from a $\pm 10 \%$ range in bulk density. In contrast, the uncertainty in time of sampling $t$ (lines A vs. C) or in how much BC inputs were reduced (lines A vs. B or lines C vs. D) each contribute only about $12 \%$ uncertainty in $\tau$. Line $\mathrm{E}$ shows that if $\mathrm{BC}$ inputs have not been reduced as much as we assume, the true turnover may be even faster than we have estimated here.

Black carbon with ages $>1000$ years has been found preserved in soil, suggesting a long turnover time (millennia) in some cases (Forbes et al., 2006), but like all soil organic matter, $\mathrm{BC}$ exists in a continuum of turnover times. If all $\mathrm{BC}$ had such long turnover times there would be much more BC

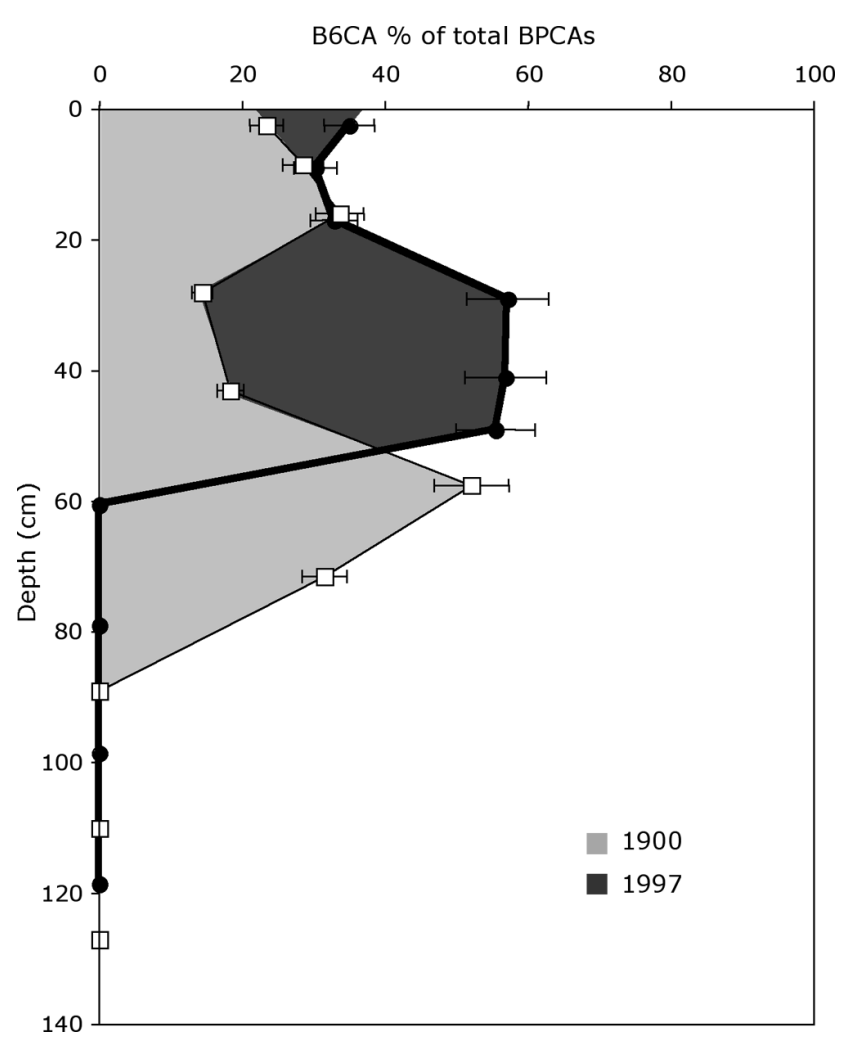

Fig. 3. Mellitic acid (B6CA) is a molecular marker that is only released from the highly condensed, aromatic (and recalcitrant) core of BC structures. Relative contributions of B6CA to the total BPCA for 1900 (thin black line, open squares), and 1997 (thick black line, filled circles). Error bars show the standard deviation of replicate laboratory analyses ( $n=2-3$ per soil sample). After one century of soil $\mathrm{BC}$ loss relative contributions of $\mathrm{B} 6 \mathrm{CA}$ increased indicating that mostly the recalcitrant BC is left behind (see also Fig. 4).

present in soil, given what is known about BC inputs rates to soil (as reviewed by Forbes et al., 2006; Preston and Schmidt, 2006) (at equilibrium, stock=input rate $\times$ turnover time).

The BC turnover times in this study were calculated under the assumption that $\mathrm{BC}$ is homogenous with respect to turnover (see Sect. 2.7), but it is almost certain that BC in soil has a range of turnover times (Lehmann, 2007), as we have shown with the changing quality of BC in (Sect. 3.3). It is possible, for example, that the observed $25 \%$ reduction in BC happened very quickly after reduction of inputs circa 1900 (i.e., $25 \%$ of BC had a very rapid turnover time) while the rest had a much slower turnover time. This would be consistent with our finding that almost all B6CA was retained while much of the other forms of $\mathrm{BC}$ were lost. As with other types of soil organic carbon, turnover times of $\mathrm{BC}$ are likely to vary with chemical form, physical form, and depth and micro-environment in the soil. Moreover, the residence time reported here is a whole-profile average value whereas there is likely a gradient in turnover time with depth. We emphasize that the best-estimate turnover time presented here is 


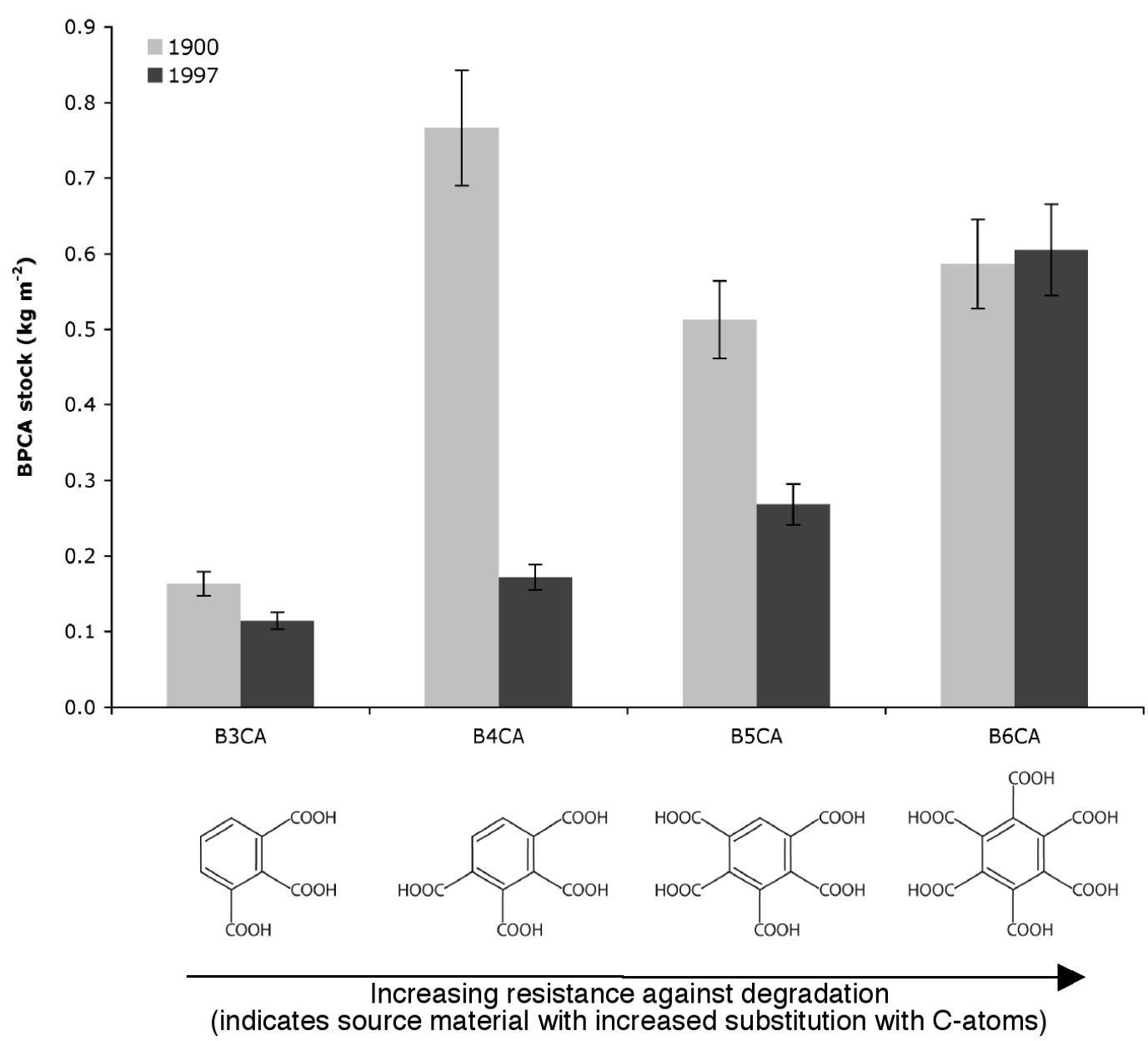

Fig. 4. Benzene polycarboxylic acid (BPCA) pattern of black carbon for whole soil profiles (1900 and 1997) as influenced by time for whole soil profiles of 1900 and 1997 under pristine steppe $\left(B 3 C A=\sum\right.$ hemimellitic, trimellitic, trimesic acids; B4CA= $\sum$ pyromellitic, prehnitic, mellophanic acids; B5CA=benzene pentacarboxylic acid; B6CA=mellitic acid). Error bars show the standard deviation of replicate laboratory analyses $(n=2-3$ per soil sample).

a conservative value and that turnover, or at least a significant fraction of soil BC, could be even faster than predicted. In fact, when splitting the BPCAs into two pools with presumed different turnover times, we got an indication that confirms the heterogeneous nature of BC. A fast turnover pool (relatively labile BPCA compounds) is represented by the sum of B3CA, B4CA and B5CA, and a slow turnover pool (relatively stable BPCA compounds) is represented by B6CA. As with the bulk soil, we analyzed the profile-total change in stock between the historical and 1997 samplings. Figure 6 gives the range of turnover times for these two pools, for scenarios that span reasonable values for the time-betweensampling, cessation of fire inputs, and bulk density (Table 2). The fast pool has a range of turnover times between 55 and 120 years, depending on the scenario, with a best estimate turnover time of $83 \mathrm{y}$ (Fig. 6A). The slow pool turnover had a best-estimate turnover time of 812 y (Fig. 6b), with a range of 350-12360 y. The upper bound on the range, however, was very sensitive to uncertainty in bulk density because the decrease in B6PA stock between samplings was so small (in Eq. 3, as $b$ approaches 1 , turnover time approaches infinity, meaning no decay).

As with other types of soil organic carbon, the rate of soil $\mathrm{BC}$ turnover is a function of its formation conditions (e.g., fire temperature, duration, and oxygen supply) (Baldock and Smernik, 2002; Brodowski et al., 2006; Cheng et al., 2006; Lehmann 2007) and the environment (e.g., climate, soil aggregation, mineralogy, biological activity) (Masiello, 2004). Variations in formation conditions and the environment support the idea of $\mathrm{BC}$ as a continuum of more or less condensed elemental carbon with different chemical and physical reactivity (Forbes et al., 2006; Preston and Schmidt, 2006). Oxidized BC has been found in dissolved organic matter in a forest soil with visible pieces of 100-year-old charcoal in the topsoil, where filamentous bacteria were seen growing (Hockaday et al., 2006). Black carbon particles, deposited about 6000 years ago and collected from a tropical subsoil, displayed a highly aromatic core, and a highly functionalized 


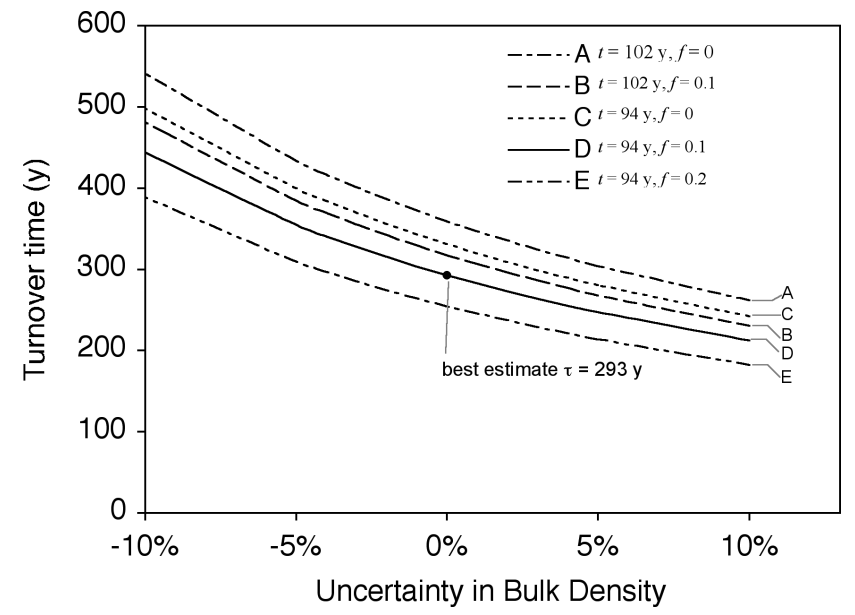

Fig. 5. Estimated turnover time of black carbon in the Russian steppe soil versus uncertainty in bulk density of the 1900 soil, shown as \% change from the 1997 bulk density. The solid circle shows the best estimate of $293 \mathrm{y}$, calculated with Eq. 3 and previously published values for original sampling date (1903) and bulk density (no change from present), and assuming BC inputs from fires post- 1900 were reduced to $10 \%$ of those pre-1900. The lines show the sensitivity of turnover time to the estimated uncertainty range in time since sampling $(t)$, reduction of BC inputs post 1900 (e.g., $f=0.1$ denotes inputs reduced to $10 \%$ of pre- 1900 value), and bulk density of the 1900 soil, which affects the estimate of change in stock ( $b$; see Table 2). Each line shows $\tau$ for a different combination of $t$ and $f$ while bulk density varies on the x-axis. Lines A and B bracket the minimum and maximum possible $\tau$. Our estimate of $\tau$ is much more sensitive to uncertainty in bulk density (two-fold effect) than it is to uncertainty in sampling year (lines A vs. C) or reduction in $\mathrm{BC}$ inputs (lines $\mathrm{A}$ vs. $\mathrm{B}$ or lines $\mathrm{C}$ vs. D) which each contribute about $12 \%$ uncertainty in $\tau$. Line $\mathrm{E}$ shows that if $\mathrm{BC}$ inputs have not been reduced as much as we assume, the true turnover may be even faster than we have estimated here.

outer surface (carboxylic and phenolic groups) where microbial and chemical degradation had taken place (Lehmann et al., 2005). Incubation studies show that BC, by providing more growth surfaces, stimulates the growth of microorganisms, which in turn break down the BC. With the addition of glucose, $\mathrm{BC}$ mineralization is further enhanced. Cometabolism could thus be an important mechanism of $\mathrm{BC}$ decay (Hamer et al., 2004). Bird et al. (1999) found that $\mathrm{BC}$ can undergo natural degradation or loss, but like in our study, they could only speculate as to the mechanisms: oxidation to $\mathrm{CO}_{2}$, illuviation to deeper parts of the soil profile, or solubilization and loss as dissolved organic matter. Preferential erosion of $\mathrm{BC}$ has been observed in steep-sloped tropical soils (Rumpel et al., 2006), but is very unlikely to have played a significant role in our study site. All these mechanisms have been observed in various studies (see above), but further studies are needed to elucidate the conditions and controls of BC turnover from different pathways, to understand the $\mathrm{BC}$ budget in different soils.
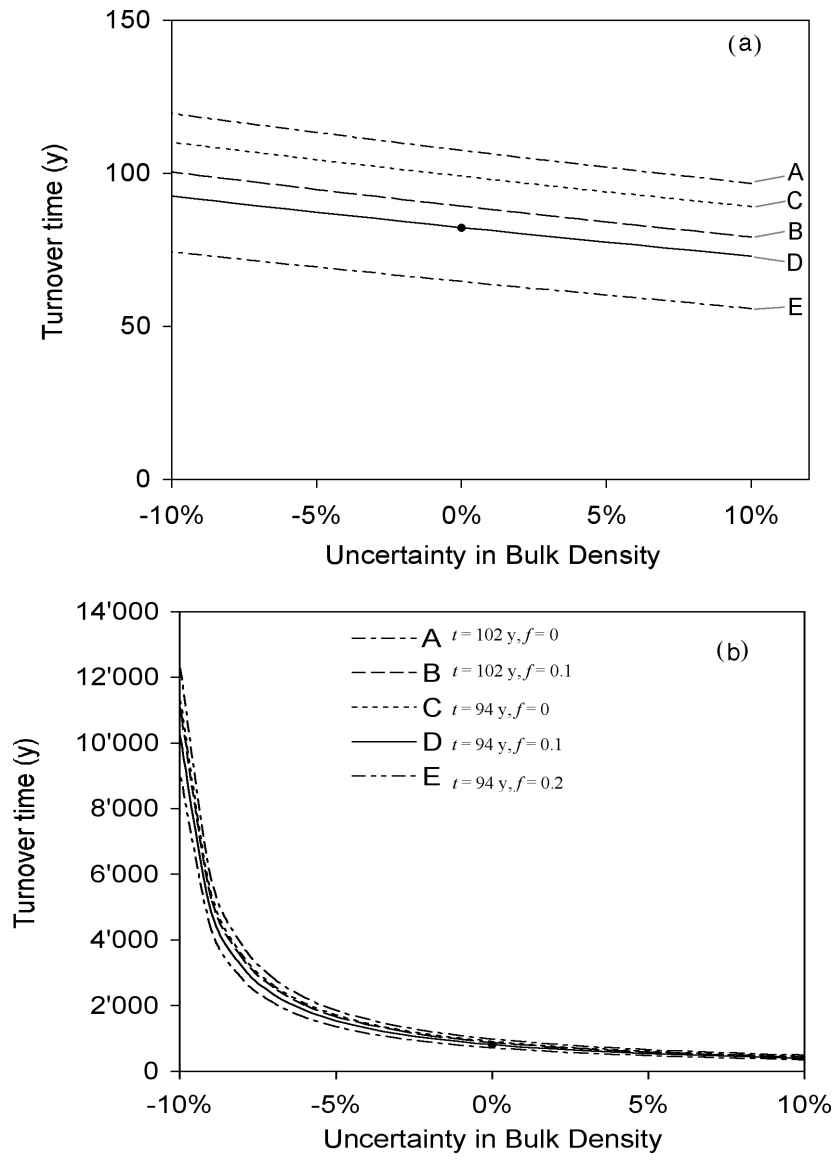

Fig. 6. Range of turnover times for the (a) fast BPCA pool (sum of B3CA, B4CA, B5CA) and (b) the slow BPCA pool (B6CA). The solid circles show the best estimate for the fast pool (a) of $83 \mathrm{y}$ and the slow pool (b) of $812 \mathrm{y}$. Scenarios A to E are described in Sect. 2 and Fig. 5.

\subsection{Role of black carbon in the global carbon cycle}

In addition to the reduction of $\mathrm{BC}$ inputs due to cessation of biomass burning at our study sites, atmospheric trends over the past 100 years may have affected the loss of BC from the soil. There has been trend of increasing precipitation and temperature since the 1950's in our study area (Sentsova, 2002), which could have altered the decomposition rate of the soil organic matter by increasing soil moisture and chemical and microbial activity. The influence of environmental conditions on BC degradation is not well known, but warming can enhance decomposition even of relatively recalcitrant organic matter (Knorr et al., 2005). Thus it is possible that these climatic trends have accelerated $\mathrm{BC}$ degradation rates in this region relative to their rates before 1950. In that case, our estimated turnover time is possibly slower than expected for the current climatic conditions, since some of the time period included in this analysis, around the turn of the previous century, had a less favorable climate for decomposition in this region. 
The region's subsoils have also lost $\mathrm{Ca}^{2+}$, which was present as calcium carbonate over the past 100 years, which has been linked to the trend in increasing precipitation (Lapenis et al., 2008). It is considered likely that calcium is involved in stabilization reactions with BC (Czimczik and Masiello, 2007), and there is circumstantial evidence that the loss of calcium from soil is associated with the loss of $\mathrm{BC}$ (Clough and Skjemstad, 2000).

Black carbon in this soil turns over on a $182-541$ y timescale, which is much faster than previously thought for soil BC (IPCC, 2001). Moreover, this BC turns over more rapidly than the bulk organic matter at this site (Torn et al., 2002), meaning that the $\mathrm{BC}$ we analyzed here is more labile than much of the other soil carbon constituents. For the first time we directly could demonstrate (using molecular marker analysis) that only the stocks of less-condensed (and thus more easily degradable) BC structures decreased, whereas the highly condensed (and more recalcitrant) structures from the core of the BC survived unchanged over the 100-year period. During the coming centuries, $\mathrm{BC}$ degradation could level off, once the less-condensed BC structures have been degraded leaving the highly condensed (and more recalcitrant) BC structures behind.

In the search for mechanisms of soil carbon stabilization, three main mechanisms have been proposed: physical protection by aggregates, mineral association, and intrinsic chemical recalcitrance (Sollins et al., 1996). While several recent studies now suggest that plant tissue is not as chemically recalcitrant as previously thought (e.g., von Lutzöw, 2006; Marschner et al., 2008), BC remains a prime candidate for an intrinsically recalcitrant material in soil. Thus, our results for BC turnover appear to remove one of the last potential candidates for chemically recalcitrant carbon inputs, termed passive or inert in soil organic matter models. BC may, however, be stabilized by physical interactions. There is evidence that $\mathrm{BC}$ together with other organic soil compounds can be very stable when stabilized in microaggregates $(<250 \mu \mathrm{m})$ and/or bound in organo-mineral complexes (for example with iron or aluminum oxides) and clay minerals in the soil where it is protected from fast degradation (Torn et al., 1997; Golchin et al., 1997; Eusterheus et al., 2005; Brodowski et al., 2006). An improved process-level understanding of the physical and mineral controls on $\mathrm{BC}$ and $\mathrm{OC}$ turnover is needed to better quantify the role that $\mathrm{BC}$ plays in the global carbon cycle and more generally that soil can play in sequestrating carbon or generating feedback that amplifies climate change.

\section{Conclusions}

In this study we generated the first whole-profile estimate of $\mathrm{BC}$ stocks and turnover in the field by using soils sampled 100 years apart in a Russian steppe preserve. From these results we draw the following conclusions.
(1) When steppe fires occurred regularly (until year 1900) black carbon stocks were large (7-10\% of total organic C), and the peak BC stock was below $30 \mathrm{~cm}$, which would be missed in typical soil inventories focusing on the topsoil only.

(2) When the input BC in fire residues stopped, stocks of BC decreased significantly (25\%) within a century, translating into a centennial soil BC turnover (293 years as best estimate) - much faster than so-called inert or passive carbon in ecosystem models.

(3) Only the stocks of less-condensed (and thus more easily degradable) BC structures decreased, whereas the highly condensed (and more recalcitrant) structures from the core of the BC survived unchanged over the 100-year period.

(4) Soil BC can cycle on century time scales, and thus is likely not as recalcitrant as previously thought, and other explanations for very old soil carbon are needed.

Acknowledgements. This work was partially supported by the Office of Science, U.S. Department of Energy under Contract No. DE-AC02-05CH11231. A. Lapenas was funded by the NSF Ecosystem Studies Program and K. Hammes by the University of Zurich and received a stipend through the Lawrence Berkeley National Laboratory. Fieldwork was supported by E. Eckmeier. Technical assistance was provided by B. Kaegi and M. Hilf (University of Zürich) and C. Castanha and F. Hopkins (Lawrence Berkeley National Laboratory).

Edited by: J. Leifeld

\section{References}

Andreae, M. O. and Gelencsér, A.: Black carbon or brown carbon? The nature of light-absorbing carbonaceous aerosols, Atmos. Chem. Phys., 6, 3131-3148, 2006, http://www.atmos-chem-phys.net/6/3131/2006/.

Ansley, R. J., Boutton, T. W., and Skjemstad, J. O.: Soil organic carbon and black carbon storage and dynamics under different fire regimes in temperate mixed-grass savanna, Global Biogeochem. Cy., 20, GB3006, doi:10.1029/2005GB002670, 2006.

Balesdent, J., Wagner, G. H., and Mariotti, A.: Soil organic matter turnover in long-term field experiments as revealed by carbon-13 natural abundance, Soil Sci. Soc. Am. J., 52, 118-124, 1988.

Baldock, J. A. and Smernik, R. J.: Chemical composition and bioavailability of thermally altered Pinus resinosa (Red pine) wood, Org. Geochem., 33, 1093-1109, 2002.

Bell, J. C. and McDaniel, P. A.: Mollisols, in: Handbook of Soil Science, edited by: Sumner, M. E., CRC Press, Boca Raton, FL., E-286-E-307, 2000.

Bird, M. I., Moyo, C., Veenendal, E. M., Lloyd, J., and Frost, P.: Stability of elemental carbon in a savanna soil, Global Biogeochem. Cy., 13(4), 923-932, 1999.

Brodowski, S.: Origin, function, and reactivity of black carbon in the arable soil environment, $\mathrm{PhD}$ thesis, Bonner Bodenkundliche Abhandlungen Band 42, p. 183, ISSN 0939-7809 (D5), 2005.

Brodowski, S., Rodionov, A., Haumaier, L., Glaser, B., and Amelung, W.: Revised black carbon assessment using benzene polycarboxylic acids, Org. Geochem., 36, 1299-1310, 2005. 
Brodowski, S., John, B., Flessa, H., and Amelung, W.: Aggregateoccluded black carbon in soil, Eur. J. Soil Sci., 57, 539-546, 2006.

Brodowski, S., Amelung, W., Haumaier, L., and Zech, W.: Black carbon contribution to stable humus in German arable soils, Geoderma, 139(1-2), 220-228, 2007.

Cheng, C.-H., Lehmann, J., Thies, J. E., Burton, S. D., and Engelhard, M. H.: Oxidation of black carbon by biotic and abiotic processes, Org. Geochem., doi:10.1016/j.orggeochem.2006.06.022, 2006.

Clough, A. and Skjemstad, J. O.: Physical and chemical protection of soil organic carbon in three agricultural soils with different contents of calcium carbonate, Aust. J. Soil Res., 38(5), 10051016, 2000.

Czimczik, C. and Masiello, C. A.: Controls on black carbon storage in soils, Global Biogeochem. Cy., 21, GB3005, doi:10.1029/2006GB002798, 2007.

Esterhues, K., Rumpel, C., and Kögel-Knabner, I.: Stabilization of soil organic matter isolated via oxidative degradation, Org. Geochem., 36, 1567-1575, 2005.

Forbes, M. S., Raison, R. J., and Skjemstad, J. O.: Formation, transformation and transport of black carbon (charcoal) in terrestrial and aquatic ecosystems. Sci. Total Environ., 370, 190-206, 2006.

Glaser, B. and Amelung, W.: Pyrogenic carbon in native grassland soils along a climosequence in North America, Global Biogeochem. Cy., 17(2), 1064, doi:10.1029/2002GB002019, 2003.

Golchin, A., Baldock, J. A., Clarke, P., Higashi, T., and Oades, J. M.: The effects of vegetation and burning on the chemical composition of soil organic matter of a volcanic ash soil as shown by ${ }^{13} \mathrm{C}$ NMR spectroscopy. II. Density fractions, Geoderma, 76, 175-192, 1997.

Goldberg, E. D.: Black carbon in the environment, John Wiley \& Sons, Inc., New York, 1985.

Hamer, U., Marschner, B., Brodowski, S., and Amelung, W.: Interactive priming of black carbon and glucose mineralization, Org. Geochem., 35, 823-830, 2004.

Hammes, K., Schmidt, M. W. I., Smernik, R. J., Currie, L. A., Ball, W. P., Nguyen, T. H., Louchouarn, P., Houel, S., Gustafsson, Ö, Elmquist, M., Cornelissen, G., Skjemstad, J. O., C.A. Masiello, C. A., Song, J., Peng, P., Mitra, S., Dunn, J. C., Hatcher, P. G., Hockaday, W. C., Smith, D. M., Hartkopf-Fröder, C., Böhmer, A., Lüer, B., Huebert, B. J., Amelung, W., Brodowski, S., Huang, L., Zhang, W., Gschwend, P. M., Flores-Cervantes, D. X., Largeau, C., Rouzaud, J.-N., Rumpel, C., Guggenberger, G., Kaiser, K., Rodionov, A., Gonzalez-Vila, F. J., GonzalezPerez, J. A., de la Rosa, J. M., Manning, D. A. C., LópezCapél, E., and Ding, L.: Comparison of black carbon quantification methods to measure fire-derived (black/elemental) carbon in soils and sediments using reference materials from soil, water, sediment and the atmosphere, Global Biogeochem. Cy., 21, GB3016, doi:10.1029/2006GB002914, 2007.

Hockaday, W. C., Grannas, A. M., Kim, S., and Hatcher, P. G.: Direct molecular evidence for the degradation and mobility of black carbon in soils from ultrahigh-resolution mass spectral analysis of dissolved organic matter from a fire-impacted forest soil, Org. Geochem., 37, 501-510, 2006.
Intergovernmental Panel on Climate Change (IPCC), Climate Change 2001: The Scientific Basis, edited by: Houghton, J. T., Ding, Y., Griggs, D. J., et al., Cambridge Univ. Press, New York, ISBN 0521807670, 2001.

Ivanov, V. A.: Report on 100 years of observations at Kamennaya Steppe national park, Reprint, 270, Kamennaya Steppe, 1991 (in Russian).

Jenkinson, D. S.: The turnover of organic carbon and nitrogen. Philos. T. Roy. Soc. B, 329, 361-368, 1990.

Kleber, M., Rößner, J., Chenu, C., Glaser, B., Knicker, H., and Jahn, R.: Prehistoric alteration of soil properties in a central German chernozemic soil: In search of pedological indicators for prehistoric activity, Soil Sci., 168, 292-306, 2003.

Knorr, W., Prentice, I. C., House, J. I., and Holland, E. A.: Longterm sensitivity of soil carbon turnover to warming, Nature, 433, 2998-301, 2005.

Koch, D. and Hansen, J.: Distant origins of Arctic black carbon: A Goddard Institute for Space Studies ModelE experiment, J. Geophys. Res., 110, D04204, doi:10.1029/2004JD005296, 2005.

Kucharik, C. J., Brye, K. R., Norman, J. M., Foley, J. A., Gower, S. T., and L.G. Bundy, L. G.: Measurements and modeling of carbon and nitrogen cycling in agroecosystems of Southern Wisconsin: Potential for SOC sequestration during the next 50 years, Ecosystems, 4, 237-258, 2001.

Kuhlbusch, T. A. J.: Black carbon and the carbon cycle, Science, 280, 1903-1904, 1998.

Lapenis, A. G., Torn, M. S., Harden, J. W., Hollocker, K., Babikov, B. V., Timofeev, A. I., Hornberger, M. I., and Nattis, R.: Scientists unearth clues to soil contamination by comparing old and new soil samples. EOS, Transactions, American Geophysical Union, 81(6), 53, 59-60, 2000.

Lapenis, A. G., Lawrence, G. B., Baily, S., Aparin, B. F., Shiklomanov, A. I., Speranskaya, N. A., Torn, M. S., and Calef, M.: Climatically driven loss of calcium in steppe soil as a sink for atmospheric carbon, Global Biogeochem. Cy., 22, GB2010, doi:10.1029/2007GB003077, 2008.

Lehmann, J., Liang, B., Solomon, D., Lerotic, M., Luizão, F., Kinyangi, J., Schäfer, T., Wirick, S., and Jacobsen, C.: Nearedge X-ray absorption fine structure (NEXAFS) spectroscopy for mapping nano-scale distribution of organic carbon forms in soil: Application to black carbon particles, Global Biogeochem. Cy., 19, GB1013, doi:10.1029/2004GB002435, 2005.

Lehmann, J.: Bio-energy in the black, Front. Ecol. Environ., 5, 381387, 2007.

Marschner, B., Brodowski, S., Dreves, A., Gleixner, G., Grootes, P. M., Hamer U., Heim A., Jandl, G., Jih, R., Kaiser, K., Kalbitz, K., Kramer, C., Leinweber, P., Rethemeyer, J., Schmidt, M. W. I., Schwark, L., and Wiesenberg, G. L. B.: How relevant is recalcitrance for the stabilization of organic matter in soils?, J. Plant Nutr. Soil Sc., 171, 91-110, 2008.

Masiello, C. A.: New directions in black carbon organic geochemistry, Mar. Chem., 92, 201-213, 2004.

Masiello, C. A. and Druffel, E. R. M.: Black carbon in deep-sea sediments, Science, 280(5371), 1911-1913, 1998.

Middelburg, J. J., Nieuwenhuize, J., and van Breugel, P.: Black carbon in marine sediments, Mar. Chem., 65, 245-252, 1999.

Mikhailova, E. A. and Post, C. J.: Organic carbon stocks in the Russian Chernozem, Eur. J. Soil Sci., 57, 330-336, 2006. 
Parton, W. J., Ojima, D. S., Cole, C. V., and Schimel, D. S.: A general model for soil organic matter dynamics: sensitivity to litter chemistry, texture, and management, in: Quantitative Modeling of Soil Forming Processes, edited by: edited by: Bryant, R. S. and Arnold, R. W., Soil Science Society of America, Madison, 147-167, 1994.

Preston, C. M. and Schmidt, M. W. I.: Black (pyrogenic) carbon: a synthesis of current knowledge and uncertainties with special consideration of boreal regions, Biogeosciences, 3, 397-420, 2006, http://www.biogeosciences.net/3/397/2006/.

Randerson, J. T., Thompson, M. V., Malmstrom, C. M., Field, C. B., and Fung, I. Y.: Substrate limitations for heterotrophs: Implications for models that estimate the seasonal cycle of atmospheric $\mathrm{CO}_{2}$, Global Biogeochem. Cy., 10, 585-602, 1996.

Rodionov, A., Amelung, W., Haumaier, L., Urusevskaja, I., and Zech, W.: Black carbon in the zonal steppe soils of Russia, J. Plant Nutr. Soil Sc., 169, 363-369, 2006.

Rumpel, C., Chaplot, V., Planchon, O., Bernadou, J., Valentin, C., and Mariotti, A.: Preferential erosion of black carbon on steep slopes with slash and burn agriculture, Catena, 65, 30-40, 2006.

Schmidt, M. W. I.: Carbon budget in the black, Nature, 427, 305306, 2004.

Sentsova, N. I.: Spatial and temporal variations in the formation of the Kamennaya steppe water regime, Water Resources, 29, 622625, 2002.

Skjemstad, J. O., Clarke, P., Taylor, J. A., Oades, J. M., and McClure, S. G.: The chemistry and nature of protected carbon in soil, Aust. J. Soil Res., 34, 251-277, 1996.
Sollins, P., Homann, P., and Caldwell, B. A.: Stabilisation and destabilisation of soil organic matter: mechanisms and controls, Geoderma, 74, 65-105, 1996.

Stolbovoi, V. and McCallum, I.: CD-ROM "Land Resources of Russia”, International Institute for Applied Systems Analysis and the Russian Academy of Science, Laxenburg, Austria, 2002.

Torn, M. S., Trumbore, S. E., Chadwick, O. A., Vitousek, P. M., and Hendricks, D. M.: Mineral control of soil organic carbon storage and turnover, Nature, 389, 170-173, 1997.

Torn, M. S., Lapenis, A. G., Timofeev, A., Fischer, M. L., Babikov, B. V., and Harden, J. W.: Organic carbon and carbon isotopes in modern and 100-year-old-soil archives of the Russian steppe, Glob. Change Biol., 8, 941-953, 2002.

Trumbore, S. E.: Comparison of carbon dynamics in two soils using measurements of radiocarbon in pre-and post-bomb soils, Global Biogeochem. Cy., 7, 275-290, 1993.

Veldkamp, E.: Organic carbon turnover in three tropical soils under pasture after deforestation, Soil Sci. Soc. Am. J., 58, 175-180, 1994.

v. Lützow, M., Kögel-Knabner, I., Ekschmitt, K., Matzner, E., Guggenberger, G., Marschner, B., Flessa, H.: Stabilization of organic matter in temperate soils: mechanisms and their relevance under different soil conditions - a review, Eur. J. Soil Sci., 57(4), 426-445, doi:10.1111/j.1365-2389.2006.00809.x, 2006.

Wang, X., Peng, P. A., and Ding, Z. L.: Black carbon records in Chinese Loess Plateau over the last two glacial cycles and implications for paleofires, Palaeogeogr. Palaeocl., 223, 9-19, 2005. 